\title{
APLIKASI AKAD MURABAHAH PADA LEMBAGA KEUANGAN SYARIAH
}

\author{
Roifatus Syauqoti \\ Mahasiswi Pasca Sarjana Program Studi Hukum Ekonomi Syariah \\ Universitas Darussalam Gontor, \\ Email-roifatussyauqi@gmail.com
}

\begin{abstract}
Mohammad Ghozali
Dosen Senior Fakultas Syariah dan Pasca Sarjana Program studi Hukum Ekonomi Syariah Universitas Darussalam Gontor, mohammadghozali@unida.gontor.ac.id
\end{abstract}

\begin{abstract}
Abstrak
Pertambahan kebutuhan masyarakat terkendala pada kesibukan dan ketidakmampuan dalam memenuhi kebutuhan sehingga masyarakat membutuhkan alternatif untuk membantunya dalam pemenuhan kebutuhan. Lembaga Keuangan Syariah (LKS) muncul sebagai alternatif bagi masyarakat dalam memenuhi kebutuhannya. Produk utama yang ditawarkan LKS kepada masyarakat adalah murabahah karena sedikitnya resiko dalam aplikasinya. Namun aplikasi murabahah menimbulkan banyak kritik di kalangan masyarakat. Bank syariah sering disebut sebagai "bank murabahah" karena murabahah mendominasi dan modifikasi pada aplikasi murabahah yang dianggap sama seperti kredit pada bank konvensional. Kajian ini merupakan kajian pustaka dengan analisis deduktif, yaitu penulis menganalisis dari yang umum ke khusus sehingga dapat diambil kesimpulan. Hasil penelitian ini menyimpulkan bahwa dalam aplikasi murabahah yang ada pada perbankan syariah menjadikan bank syariah sebagai penyedia dana bukan sebagai penjual. Akad murabahah yang ada pada fiqih klasikpun telah banyak mengalami modifikasi. Modifikasi pada akad murabahah inilah yang memunculkan kritik di kalangan masyarakat. Modifikasi akad murabahah meliputi akad murabahah yang mengikat nasabah sebelum bank memiliki barang yang diinginkan nasabah sehingga memunculkan bai' ma'dum, murabahah lil amri bi al-syira' yang dianggap haram oleh sebagian ulama karena merupakan celah riba, dan murabahah bil wakalah yang hukumnya boleh menurut Fatwa DSN-MUI namun adanya akad wakalah memudahkan munculnya kecurangan dari pihak nasabah yang akan membuat akad murabahahnya tidak sah.
\end{abstract}

Kata Kunci: Lembaga Keuangan Syariah, Murabahah lil Amri bi alSyira', Murabahah bil Wakalah. 


\section{PENDAHULUAN}

Selaras dengan perkembangan zaman, maka kebutuhan dan kesibukan masyarakat juga terus bertambah. Pertambahan kebutuhan masyarakat terkendala pada kesibukan dan ketidakmampuan dalam memenuhi kebutuhan secara tunai maka masyarakat membutuhkan alternatif untuk membantunya dalam pemenuhan kebutuhan. ${ }^{1}$

Lembaga Keuangan Syariah ${ }^{2}$ (LKS) hadir sebagai pilihan dan alternatif pemenuh kebutuhan masyarakat secara syariah dan jauh dari kegiatan ribawi sebagaimana yang ada di Lembaga Keuangan Konvensional $^{3}$ (LKK). LKS muncul dengan konsep dan sistem yang dapat menampung tuntutan dan kebutuhan masyarakat, dengan sistem bagi hasil dan resiko, yang mengedepankan prinsip keadilan dan kebersamaan dalam berusaha, baik dalam memperoleh keuntungan maupun dalam menghadapi resiko. ${ }^{4}$

Prinsip-prinsip dasar dalam LKS diantaranya adalah prinsip titipan atau simpanan (al-wadi'ah), prinsip bagi hasil yang meliputi mudharabah dan musyarakah, prinsip jual beli yang meliputi murabahah, salam dan istishna, prinsip sewa (ijarah) dan prinsip jasa yang meliputi wakalah, kafalah, hawalah, rahn, qardh, sharf. ${ }^{5}$ Sebagian dari prinsip-prinsip ini muncul di LKS sebagai produk dari LKS dengan nama yang sama atau mengalami perubahan.

Diantara berbagai produk-produk yang ada di LKS, produk murabahah masih mendominasi dibandingkan dengan produk-produk

\footnotetext{
${ }^{1}$ Dr. 'Alauddin Za'tari, Al-Khidmah Al-Mashrafiyyah, Cetakan I, (Damaskus: Dar el-Kalam Attayyib, 2002, Hal. 217

${ }^{2}$ Lembaga Keuangan Syariah adalah lembaga yang menjalankan kegiatannya dengan prinsip hukum Islam dalam kegiatan perbankan dan keuangan berdasarkan fatwa yang dikeluarkan oleh lembaga yang memiliki kewenangan dalam penetapan fatwa di bidang syariah. Lihat Andri Soemitra, Bank dan Lembaga Keuangan Syari'ah, Cet ke 3, (Jakarta: Kencana Prenada Media Grup, 2009), hlm. 36

${ }^{3}$ Lembaga Keuangan dapat didefinisikan sebagai suatu badan usaha yang aset utamanya berbentuk aset keuangan maupun tagihan-tagihan yang dapat berupa saham, obligasi, dan pinjaman, daripada berbentuk aktiva riil seperti bangunan, perlengkapan dan bahan baku. Lihat: Martono, Bank dan Lembaga Keuangan Lain, Cet-4, (Yogyakarta: Ekonisia, 2007), hlm. 2

${ }^{4}$ Arief Budiono, "Penerapan Prinsip Syariah pada Lembaga Keuangan Syariah", Jural Law and Justice, Vol. 2, No. 1 April 2017, hlm. 55

${ }^{5}$ Muhammad Syafi'i Antonio, Bank Syariah dari Teori ke Praktik, Cet-I, (Jakarta: Gema Insani Press, 2001) hlm. 83
} 
lainnya. Hal tersebut dikarenakan produk murabahah LKS relatif bisa menerapkan prinsip kehati-hatian yang ketat dan standar sehingga risiko kerugian sangat kecil, dibandingkan dengan prinsip bagi hasil yang tingkat risiko dan kerugiannya sangat tinggi. Karena kelebihan tersebut LKS cenderung menjadikan murabahah sebagai produk unggulan yang ditawarkan kepada nasabah. ${ }^{6}$

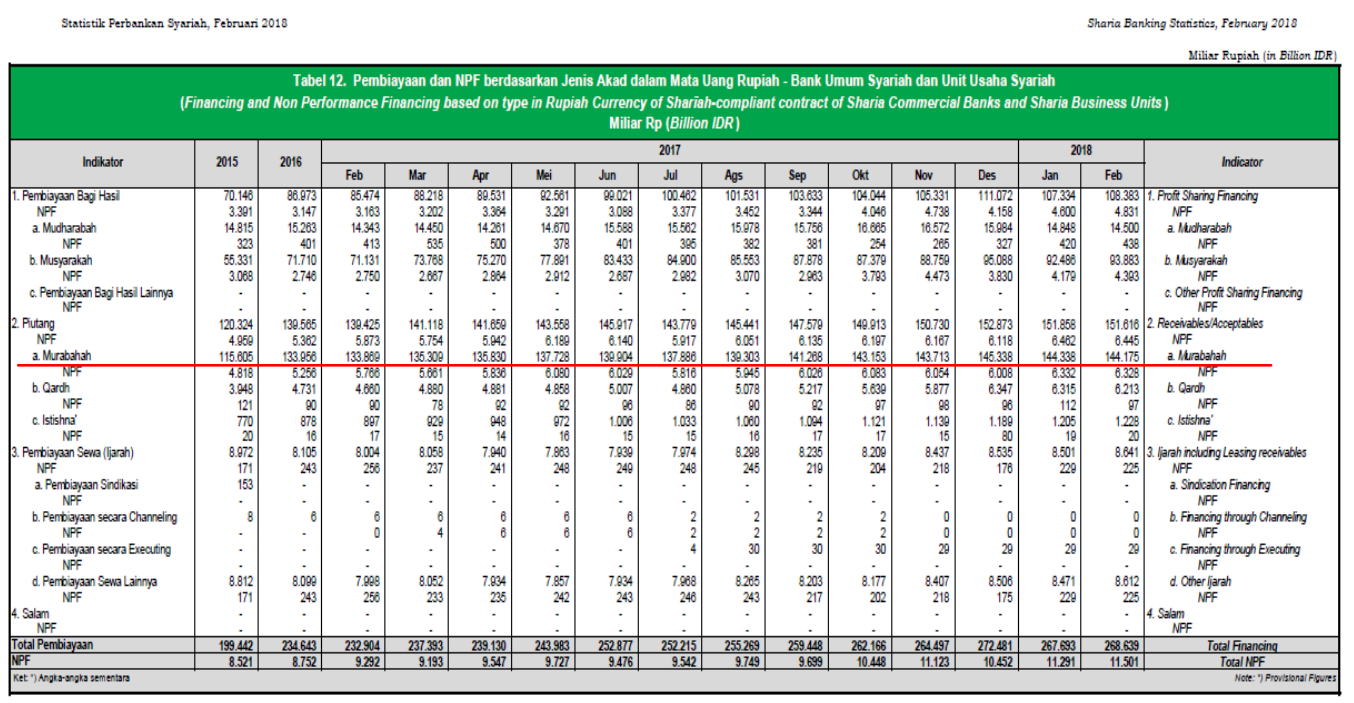

Sumber: Statistik Perbankan Syariah, www.ojk.go.id ${ }^{7}$

Dari data Statistik Perbankan Syariah yang dikeluarkan oleh OJK di atas bisa dilihat bahwa transaksi dengan akad murabahah di Bank Umum Syariah dan Unit Usaha Syariah masih unggul dibandingkan pembiayaan lainnya.

Namun dilain sisi murabahah menuai berbagai kritik terutama karena LKS mengutamakan murabahah dalam produknya, bahkan ada yang menjuluki bank syariah dengan bank murabahah. Murabahah pada prakteknya di LKS telah mengalami berbagai modifikasi menyesuaikan permintaan dari nasabah. Terkadang modifikasi tersebut tidak sesuai dengan praktik murabahah yang ada di fiqih. Sehingga tak sedikit yang menyamakannya dengan kredit di LKK.

\footnotetext{
${ }^{6}$ Ah. Azharuddin Lathif, "Konsep dan Aplikasi Akad Murabahah pada Perbankan Syariah di Indonesia", Jurnal Ahkam, Vol. XII, No. 2, Juni 2012, hlm. 69-70

Statistik Perbankan Indonesia, https://www.ojk.go.id/id/kanal/perbankan/data-danstatistik/statistik-perbankan-indonesia/Pages/Statistik-Perbankan-Indonesia---Februari-2018.aspx, diakses pada 26 April 2018, pukul 23:58 WIB
} 


\section{METODE KAJIAN}

Metode kajian yang digunakan adalah metode kajian kualitatif dengan kajian pustaka, kajian ini bersifat deskriptif analitik dimana pengumpulan data dilakukan dengan cara telaah pustaka. Analisis yang digunakan adalah analisis kualitatif dengan metode berfikir deduktif, yaitu peneliti menganalisis dari yang umum ke khusus sehingga dapat diambil kesimpulan.

\section{MURABAHAH}

\section{a. Pengertian}

Murabahah secara bahasa berasal dari kata ربح yang berarti keuntungan, ${ }^{8}$ Sedangkan menurut istilah murabahah adalah jual beli dengan harga pokok dengan tambahan keuntungan. ${ }^{9}$ Dalam pengertian lain murabahah adalah akad jual beli barang dengan harga jual sebesar biaya perolehan ditambah keuntungan yang disepakati yang di dalamnya penjual harus mengungkapkan biaya perolehan barang kepada pembeli. ${ }^{10}$

Murabahah adalah salah satu skim di perbankan syariah yang paling diminati masyarakat. Dalam pembiayaan murabahah bank menetapkan harga jual barang yaitu harga pokok perolehan barang ditambah sejumlah margin keuntungan bank. Harga jual yang telah disepakati di awal akad tidak boleh berubah selama jangka waktu pembiayaan. ${ }^{11}$

\section{b. Dasar Hukum Murabahah}

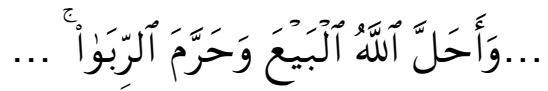

“...Padahal Allah telah menghalalkan jual beli dan mengharamkan riba..."12

\footnotetext{
${ }^{8}$ Imam al-'Alamah Ibnu Mandzur, Lisanul Arab, Cet-3, (Beirut: Dar Ehia al-Toutath al-Arabi, 1999), juz 5, hlm. 103

${ }^{9}$ Wahbah Zuhaili, al-Fiqh al-Islami wa Adillatuhu, Cet-2, (Damaskus: Dar al-Fikr, 1985), juz 4, hlm. 703

${ }^{10}$ Muhammad Yusuf, "Analisis Penerapan Pembiayaan Murabahah Berdasarkan Pesanan dan Tanpa Pesanan serta Kesesuaian dengan PSAK 102", BINUS BUSINESS REVIEW, Vol.4, No.1 Mei 2013, hlm. 15

${ }^{11}$ Yenti Afrida, "Analisis Pembiayaan Murabahah di Perbankan Syariah", JEBI (Jurnal Ekonomi dan Bisnis Islam), Vol. 1, No. 2, Juli-Desember 2016, hlm. 158

${ }^{12}$ QS. al-Baqarah: 275
} 


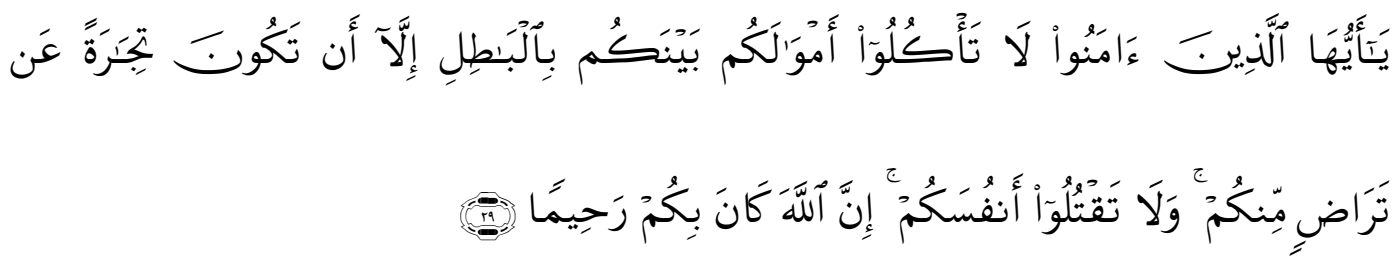

"Hai orang-orang yang beriman, janganlah kamu saling memakan harta sesamamu dengan jalan yang batil, kecuali dengan jalan perniagaan yang Berlaku dengan suka sama-suka di antara kamu. dan janganlah kamu membunuh dirimu; Sesungguhnya Allah adalah Maha Penyayang kepadamu."13

$$
\begin{aligned}
& \text { سئل النبي كسئ: أي كسب أطيب؟ فقال: عمل الرجل بيده، وكل بيع مبرور (رواه البزار، وصححه }
\end{aligned}
$$

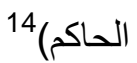

"Bahwa Nabi SAW ditanya: Apakah pekerjaan yang paling baik/afdhal?, Beliau menjawab: Pekerjaan seorang lak-laki dengan tangannya sendiri (hasil jerih payah sendiri), dan setiap jual beli yang mabrur. (Hadist Riwayat al-Bazzar, dan dishahihkan oleh al-Hakim)"

Dari kedua ayat dan hadist diatas diketahui bahwa Allah membedakan antara jual beli dan riba secara hukum. ${ }^{15}$ Allah mengharamkan riba dan menghalalkan jual beli. Jual beli menjadi halal menurut peraturan yang diakui oleh syariat, yaitu jual beli yang dilakukan suka sama suka atau saling rela di antara pihak pembeli dan pihak penjual. ${ }^{16}$

\section{c. Rukun Murabahah ${ }^{17}$}

1. Subjek akad (penjual dan pembeli)

\footnotetext{
${ }^{13}$ QS. an-Nisaa: 29

${ }^{14}$ Ibnu Hajar al-'Asqalani, Subulu as-Salam Syarhu Bulughul Maram, Cet-I, (Riyadh: Maktabah al-Ma'arif, 2006), Kitab Buyu', Nomor Hadist 735, juz 3, hlm. 7

${ }^{15}$ al-Imam Abul Fida Ismail Ibnu Katsir ad-Damasyqi, Tafsir Ibnu Katsir, terj. Bahrun Abu Bakar, Cet-I, (Bandung: Sinar Baru Algensindo, 2000), juz 3, hlm. 141

${ }_{16}$ al-Imam Abul Fida Ismail Ibnu Katsir ad-Damasyqi, Tafsir Ibnu Katsir, juz 5, hlm. 38

${ }^{17}$ Wahbah Zuhaili, al-Fiqh al-Islami wa Adillatuhu, hlm. 347
} 
Penjual adalah pihak yang memiliki objek barang yang akan diperjual belikan. Dalam transaksi melalui perbankan syariah maka pihak penjual adalah bank syariah.

Pembeli merupakan pihak yang ingin memperoleh barang yang diharapkan, dengan membayar sejumlah uang tertentu kepada penjual. Pembeli dalam transaksi perbankan syariah adalah nasabah.

2. Objek akad (harga dan barang)

Objek jual beli merupakan barang yang akan digunakan sebagai objek transaksi jual beli. Sedangkan harga merupakan harga yang disebutkan dengan jelas dan disepakati antara penjual dan pembeli.

3. ljab dan qabul

ljab dan qabul merupakan kesepakatan penyerahan dan penerimaan barang yang diperjualbelikan.

\section{d. Syarat Murabahah}

1. Pihak yang berakad, harus ikhlas dan mampu untuk melakukan transaksi jual beli.

2. Objek jual beli, barang yang diperjual belikan ada atau ada kesanggupan bagi penjual untuk mengadakan barang tersebut, milik sah penjual, berwujud dan merupakan barang halal. ${ }^{18}$ Objek yang diperjualbelikan pun harus terhindar dari cacat namun apabila cacat tersebut diketahui oleh nasabah dan disetujui maka proses jual beli tetap sah. ${ }^{19}$

3. Harga, harga jual yang ditawarkan oleh bank merupakan harga beli ditambah dengan margin keuntungan, harga jual tidak boleh berubah selama masa perjanjian, sistem dan jangka

\footnotetext{
${ }^{18}$ Ismail, Perbankan Syariah, (Jakarta: Kencana, 2011), hlm. 136-138

${ }^{19}$ Irma devita purnamasari, Panduan Lengkap Hukum Praktis Populer Kiat-Kiat Cerdas, Mudah, dan Bijak Memahami Masalah Akad Syariah, (Kaifa), hlm. 44
} 
waktu pembayaran disepakati bersama antara penjual dan pembeli. $^{20}$

4. Tidak mengandung unsur paksaan, tipuan dan mudharat. ${ }^{21}$

\section{e. Skema akad murabahah}

Dalam aplikasi murabahah perbankan syariah, bank merupakan penjual dan nasabah merupakan pembeli atau sebaliknya. Dalam hal bank menjadi penjual dan nasabah menjadi pembeli, maka bank menyediakan barang yang dibutuhkan oleh nasabah dengan membeli barang dari supplier, kemudian menjualnya kepada nasabah dengan harga yang lebih tinggi dibanding dengan harga beli yang dilakukan oleh bank syariah. Pembayaran dapat dilakukan dengan cara membayar sekaligus pada saat jatuh tempo atau melakukan pembayaran angsuran selama jangka waktu yang disepakati. ${ }^{22}$

\section{SKEMA MURABAHAH}

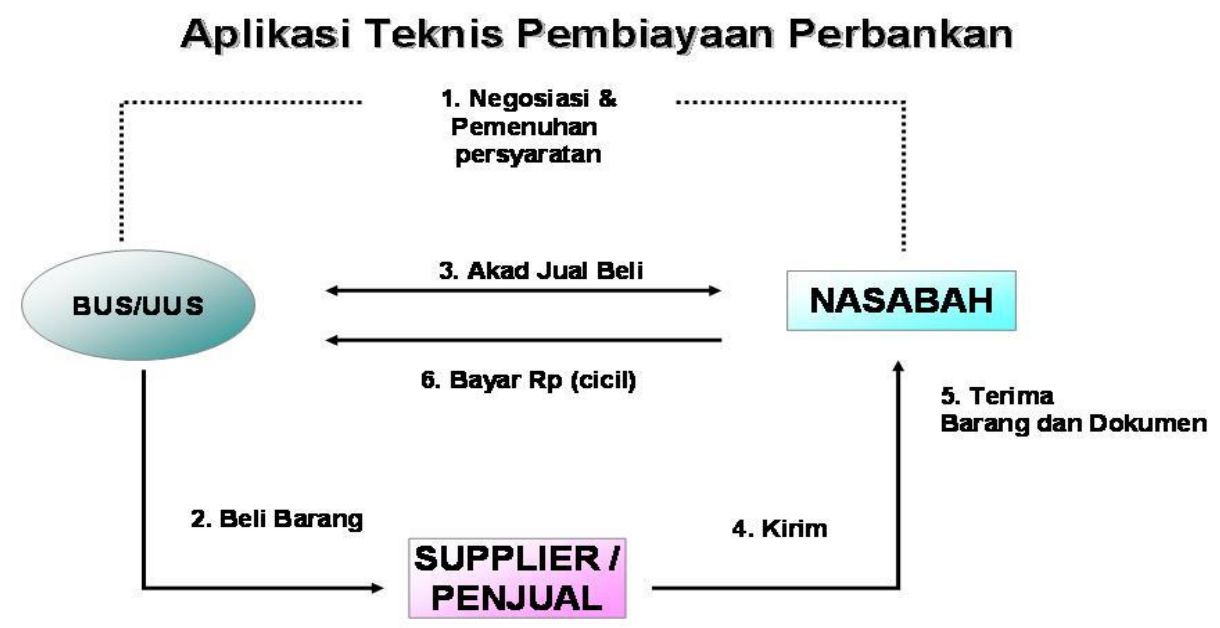

Keterangan:

1. Bank syariah dan nasabah melakukan negosiasi tentang rencana transaksi jual beli yang akan dilaksanakan.

\footnotetext{
${ }^{20}$ Ismail, Perbankan Syariah, hlm. 136-138

${ }^{21}$ Irma devita purnamasari, Panduan Lengkap Hukum Praktis Populer Kiat-Kiat Cerdas, Mudah, dan Bijak Memahami Masalah Akad Syariah, hlm. 44

${ }^{22}$ Ismail, Perbankan Syariah, hlm. 139
} 
2. Atas dasar negoisasi yang dilaksanakan antara bank syariah dan nasabah, maka bank syariah membeli barang dari supplier.

3. Bank syariah melakukan akad jual beli dengan nasabah dimana bank syariah sebagai penjual dan nasabah sebagai pembeli.

4. Supplier mengirimkan barang kepada nasabah atas perintah bank syariah.

5. Nasabah menerima barang dari supplier dan menerima dokumen kepemilikan barang tersebut.

6. Setelah menerima barang dan dokumen, maka nasabah melakukan pembayaran. Pembayaran yang lazim dilakukan oleh nasabah adalah dengan pembayaran angsuran. ${ }^{23}$

\section{ANALISIS APLIKASI AKAD MURABAHAH DI LEMBAGA KEUANGAN SYARIAH \\ Dalam praktik di LKS kontemporer, termasuk di dalamnya} perbankan syariah, bentuk murabahah dalam fiqih klasik mengalami beberapa modifikasi dan perubahan. Modifikasi inilah yang menimbulkan kritik di kalangan masyarakat. Berikut ini penulis menganalisis akad murabahah dari berbagai sudut pandang.

\section{Analisis Definisi Murabahah}

Murabahah memiliki definisi yang berbeda-beda yang menimbulkan kesalahan dalam mengartikan akad ini dan menimbulkan kesalahan pada aplikasinya.

\begin{tabular}{|l|l|l|}
\hline Pengertian Menurut: & Definisi & Kedudukan LKS \\
\hline Fatwa DSN-MUI No. & Menjual suatu barang & LKS sebagai penjual \\
04/DSN- & dengan menegaskan & \\
MUI/IV/2000 tentang & harga belinya kepada & \\
Murabahah ${ }^{24}$ & pembeli dan pembeli & \\
& membayarnya dengan & \\
\hline
\end{tabular}

${ }^{23}$ Ismail, Perbankan Syariah, hlm. 139-140

Fatwa DSN-MUI No. 04/DSN-MUI/IV/2000 tentang Murabahah, https://dsnmui.or.id/produk/fatwa/ diakses pada 21 April 2018, pukul 22:02 WIB 


\begin{tabular}{|c|c|c|}
\hline & $\begin{array}{l}\text { harga yang lebih } \\
\text { sebagai laba }\end{array}$ & \\
\hline PSAK $102^{25}$ & $\begin{array}{l}\text { Menjual barang } \\
\text { dengan harga jual } \\
\text { sebesar harga } \\
\text { perolehan ditambah } \\
\text { keuntungan yang } \\
\text { disepakati dan penjual } \\
\text { harus mengungkapkan } \\
\text { harga perolehan } \\
\text { barang tersebut pada } \\
\text { pembeli }\end{array}$ & LKS sebagai penjual \\
\hline $\begin{array}{l}\text { Surat } \\
\text { Otoritas } \\
\text { Keuangan } \\
\text { (SEOJK) No. } \\
\text { 36/SEOJK.03/2015 }\end{array}$ & $\begin{array}{l}\text { Penyediaan dana atau } \\
\text { tagihan yang dapat } \\
\text { dipersamakan dengan } \\
\text { itu untuk transaksi jual } \\
\text { beli barang sebesar } \\
\text { harga pokok ditambah } \\
\text { margin berdasarkan } \\
\text { persetujuan atau } \\
\text { kesepakatan antara } \\
\text { Bank dengan nasabah } \\
\text { yang mewajibkan } \\
\text { nasabah untuk } \\
\text { melunasi } \\
\text { hutang/kewajibannya }\end{array}$ & $\begin{array}{l}\text { LKS sebagai penyedia } \\
\text { dana }\end{array}$ \\
\hline Pasal 1 Ayat 25 UU & Pembiayaan adalah & Bank sebagai penyedia \\
\hline
\end{tabular}

25 PSAK 102 Akuntansi Murabahah, http://iaiglobal.or.id/v03/standar-akuntansikeuangan/pernyataan-sas-65-psak-102-akuntansi-murabahah, diakses pada 21 April 2018, pukul 22:04 WIB

26 Surat Edaran Otoritas jasa Keuangan (SEOJK) No. 36/SEOJK.03/2015, https://www.ojk.go.id/id/kanal/perbankan/regulasi/surat-edaran-ojk/Pages/-SEOJK-Nomor-

36032015-tentang-Produk-dan-Aktivitas-bus-uus.aspx, diakses pada 21 April 2018, pukul 22: 06 WIB 


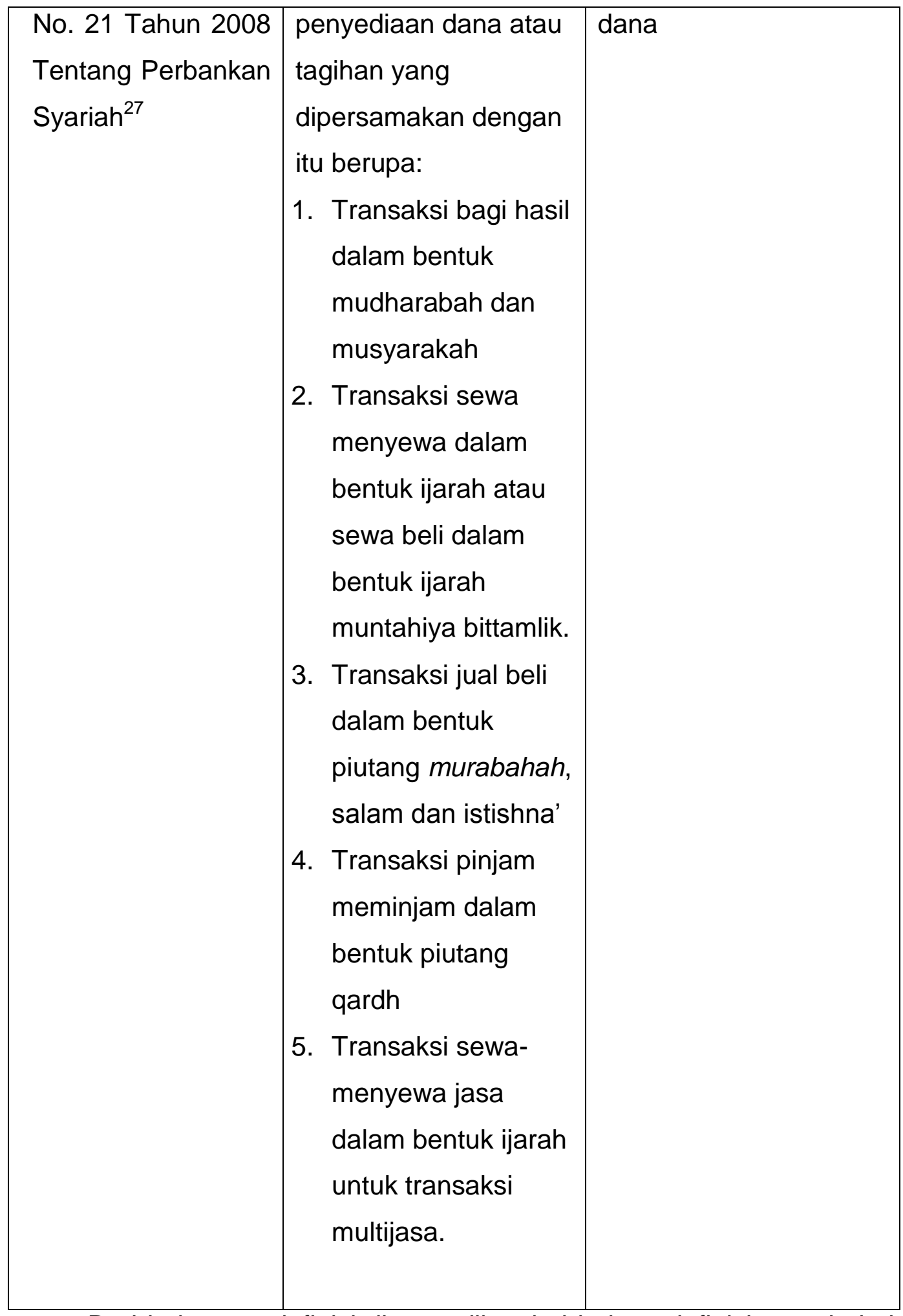

Dari beberapa definisi di atas diketahui bahwa definisi murabahah menurut Fatwa DSN-MUI No. 04/DSN-MUI/IV/2000 tentang murabahah https://www.bi.go.id/id/perbankan/syariah/Documents/UU_21_08_Syariah, diakses pada 21 April 2018, pukul 22:09 WIB 
dan PSAK 102 kedudukan LKS adalah sebagai penjual ${ }^{28}$ sedangkan menurut definisi SEOJK No. 36/SEOJK.03/2015 dan UU No. 21 tahun 2008 kedudukan LKS adalah sebagai penyedia dana ${ }^{29}$ bagi nasabah.

Jika kembali pada definisi murabahah menurut ulama klasik seperti definisi murabahah menurut Wahbah Zuhaili, yaitu murabahah adalah jual beli dengan harga pokok dengan tambahan keuntungan ${ }^{30}$ maka kedudukan LKS sebenarnya adalah sebagai penjual dan bukan hanya penyedia dana. Namun kenyataannya aplikasi murabahah di perbankan syariah menjadikan LKS sebagai penyedia dana dan bukan sebagai penjual.

\section{Analisis ketentuan dalam Fatwa DSN-MUI No. 04/DSN-MUI/IV/2000}

Ketentuan kedua dalam fatwa ini menjelaskan tentang ketentuan murabahah kepada nasabah. Beberapa ketentuan tersebut adalah sebagai berikut:

a. Nasabah mengajukan permohonan dan janji pembelian suatu barang atau aset kepada bank.

b. Jika bank menerima permohonan tersebut, ia harus membeli terlebih dahulu aset yang dipesannya secara sah dengan pedagang.

c. Bank kemudian menawarkan aset tersebut kepada nasabah dan nasabah harus menerima (membeli)-nya sesuai dengan janji yang telah disepakatinya, karena secara hukum janji tersebut mengikat; kemudian kedua belah pihak harus membuat kontrak jual beli.

\footnotetext{
${ }^{28}$ Dalam pengertian bank sebagai penjual, bank di haruskan memiliki barang yang diinginkan oleh nasabah. Namun bank tidak memiliki gudang yang menyimpan semua barang yang diinginkan oleh nasabah. Dan bank memiliki keterbatasan dalam menyediakan barang tersebut. Maka bank membeli barang tersebut dari pihak ke-3.

${ }^{29}$ Dalam pengertian bank sebagai penyedia dana bank hanya berperan sebagai pihak yang menyediakan dana bagi nasabah untuk transaksi jual beli suatu barang. Pengertian ini bisa disalah artikan oleh para praktisi dengan pemberian sejumlah dana kepada nasabah untuk membeli barang yang diinginkan oleh nasabah. Beberapa perbankan syariah pada akad murabahah ini, mengirimkan sejumlah uang ke rekening nasabah dan meminta nasabah untuk membeli sendiri barang yang diinginkannya. Objek dalam akad ini yang seharusnya barang berubah menjadi uang.

${ }^{30}$ Wahbah Zuhaili, al-Figh al-Islami wa Adillatuhu, hlm. 703
} 
Dari beberapa ketentuan di atas muncul klausula yang menguntungkan bank namun merugikan nasabah. Klausula tersebut terdapat pada ketentuan dimana nasabah mengajukan permohonan dan janji pembelian suatu barang atau aset dimana ketika LKS menawarkan aset tersebut kepada nasabah, maka nasabah harus menerima (membeli)-nya sesuai dengan janji. Para ulama syariah terdahulu bersepakat bahwa pemesan atau pembeli dalam hal ini adalah nasabah tidak boleh diikat untuk memenuhi kewajiban membeli barang yang telah dipesan. $^{31}$ Dalam hal ini nasabah tidak memiliki hak khiyar ${ }^{32}$ untuk meneruskan pembelian atau membatalkan pembelian.

\section{Analisis aplikasi akad murabahah}

Akad murabahah yang ada pada perbankan syariah diaplikasikan dengan beberapa skema diantaranya:

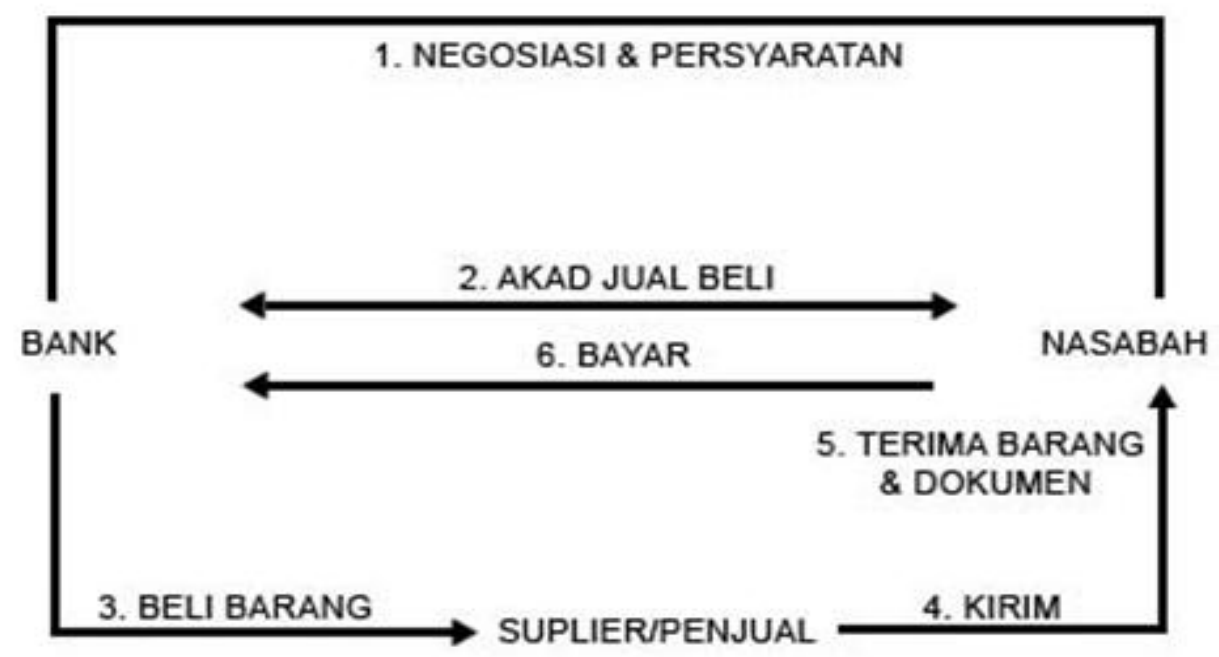

\footnotetext{
${ }^{31}$ Muhammad Syafi'i Antonio, Bank Syariah dari Teori ke Praktik, hlm. 103

${ }^{32}$ Khiyar adalah hak pilih salah satu atau kedua belah pihak yang melaksanakan transaksi untuk melangsungkan atau membatalkan transaksi yang disepakati sesuai dengan kondisi masing-masing pihak yang melakukan transaksi. Dalam hal ini nasabah tidak memiliki hak khiyar ru'yah yaitu hak pilih bagi pembeli untuk menyatakan berlaku atau batalnya jual beli yang dilakukan terhadap suatu objek yang belum dilihatnya ketika akad berlangsung.
} 
Keterangan:

a. Bank syariah dan nasabah melakukan negosiasi tentang rencana transaksi jual beli yang akan dilaksanakan.

b. Bank syariah melakukan akad jual beli dengan nasabah dimana bank syariah sebagai penjual dan nasabah sebagai pembeli. Dalam akad ini ditetapkan barang yang menjadi objek jual beli yang telah dipilih oleh nasabah dan harga jual barang.

c. Atas dasar akad yang dilaksanakan antara bank syariah dan nasabah, maka bank syariah membeli barang dari supplier.

d. Supplier mengirimkan barang kepada nasabah atas perintah bank syariah.

e. Nasabah menerima barang dari supplier dan menerima dokumen kepemilikan barang tersebut.

f. Setelah menerima barang dan dokumen, maka nasabah melakukan pembayaran. Pembayaran yang lazim dilakukan oleh nasabah adalah dengan pembayaran angsuran.

Aplikasi akad murabahah seperti skema diatas dilarang dalam Islam, karena bank sudah mengikat nasabah dengan akad jual beli sedangkan bank belum membeli atau memiliki barang yang diminta atau dipesan oleh nasabah. ${ }^{33}$ Dalam aplikasi ini juga bank telah melakukan akad jual beli kepada nasabah sedangkan objek akad belum dimiliki oleh bank. Bank telah melakukan akad atas sesuatu yang tidak nyata adanya pada saat akad, akad ini disebut dengan bai' ma'dum dalam Islam. Bai' ma'dum hukumnya haram karena mengandung gharar dan bersifat spekulatif. ${ }^{34}$

Selain aplikasi murabah diatas, terdapat aplikasi murabahah lainnya. Murabahah yang dipraktikkan pada LKS dikenal dengan

\footnotetext{
${ }^{33}$ Naimah, "Down Payment (DP) dalam Pembiayaan Murabahah (Prespektif Fikih Mu'amalah)", https://media.neliti.com/media/publications/30006-ID-down-payment-dp-dalam-pembiayaanmurabahah-perspektif-fikih-muamalah.pdf, diakses pada 21 April 2018, pukul: 22:56 WIB

${ }^{34}$ Achmad Hijri Lidinillah, Imron Mawardi, "Praktik Gharar pada Hubungan Bisnis UMKMEksportir Furnitur di Jepara" Jurnal JESTT, Universitas Airlangga, Vol. 2, No. 2, Februari 2015, hlm. 122
} 
murabahah li al-amri bi al-syira, yaitu transaksi jual beli di mana seorang nasabah datang kepada pihak bank untuk membelikan sebuah komoditas dengan kriteria tertentu, dan ia berjanji akan membeli komoditas/barang tersebut secara murabahah, yakni sesuai harga pokok pembelian ditambah dengan tingkat keuntungan yang disepakati kedua pihak, dan nasabah akan melakukan pembayaran secara cicilan berkala sesuai dengan kemampuan finansial yang dimiliki. ${ }^{35}$

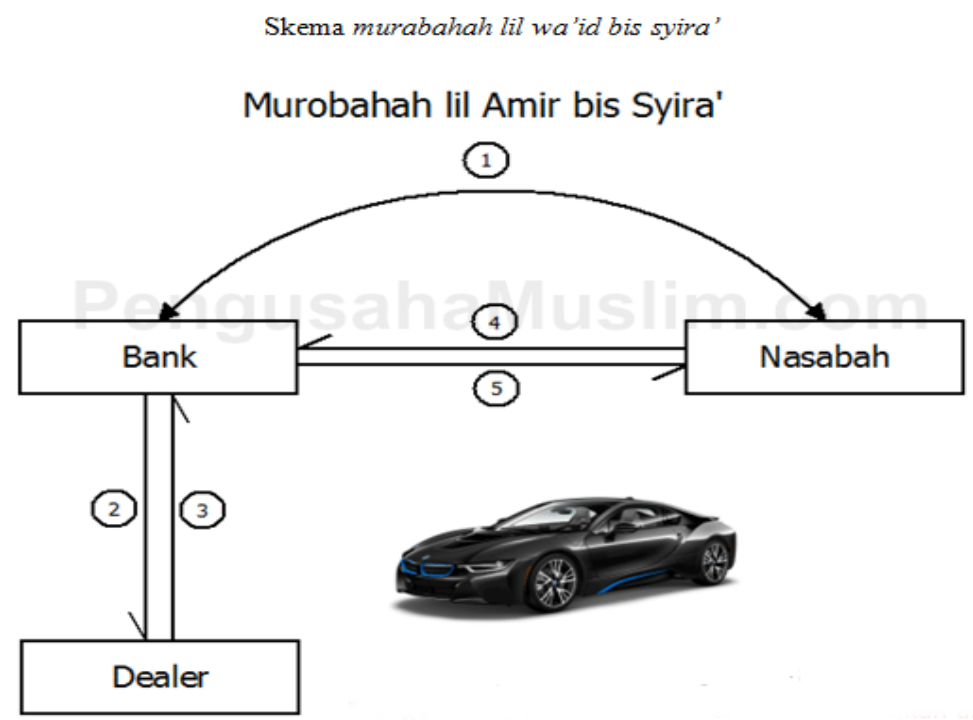

Keterangan: ${ }^{36}$

1. Nasabah menyampaikan kebutuhan barang yang ia inginkan ke bank dengan kriteria tertentu. Bank melakukan uji kelayakan nasabah, baik secara dokumen maupun yang sifatnya penilaian kejujuran.

2. Bank mencarikan barang yang diinginkan nasabah, dan membelinya dengan tunai.

3. Dealer mengirim produk ke bank dan tanggung jawab terhadap resiko barang telah berpindah ke bank.

4. Nasabah melakukan transaksi dengan bank untuk membeli barang yang telah dipesan secara kredit, dengan harga sesuai kesepakatan.

\footnotetext{
${ }^{35}$ Ah. Azharuddin Lathif, "Konsep dan Aplikasi Akad Murabahah pada Perbankan Syariah di Indonesia", Jurnal Ahkam, Vol. XII, No. 2, Juni 2012, hlm. 71

${ }^{36}$ Ammi Nur Baits, Skema Murabahah Syariah, dikutip dari https://pengusahamuslim.com/4942-
} skema-murabahah-syariah.html, diakses pada 12 Maret 2018, Pukul 02:31 WIB. 
5. Bank menyerahkan barang itu, dan nasabah membayar cicilan kepada bank.

Mengenai kedudukan hukum praktik murabahah li al-amri bi al-syira ulama kontemporer berbeda pendapat. Ada yang memperbolehkan dan ada juga yang mengakui keabsahannya atau kebolehannya. Menurut ulama yang membolehkannya kembali pada hukum asal dari muamalah yaitu diperbolehkan dan mubah kecuali ada nas shahih yang melarangnya. Ulama yang membolehkan praktik murabahah li al-amri bi al-syira adalah Imam Syafi'i. Adapun ulama yang melarang dan mengharamkan praktek ini adalah Muhammad Sulaiman al-Asyqar, Bakr ibn 'Abd Allah Abu Zayd, Rafiq al-Mishri yang beranggapan bahwa praktik murabahah li al-amri bi al-syira bukan dimaksudkan untuk melakukan jual beli, tetapi hanya sekedar rekayasa untuk menghalalkan riba, karena tujuan utama dari transaksi ini adalah uang tunai. ${ }^{37}$

Selain murabahah li al-amri bi al-syira pada realitanya bank syariah juga mempraktekkan murabahah bil wakalah, artinya bank memberikan wewenang kepada nasabah untuk melakukan jual beli terhadap barang kebutuhan nasabah dengan melakukan perjanjian wakalah (perwakilan), yang pada akhirnya nasabah hanya menyerahkan kwitansi pembelian barang sebagai bukti bahwa murabahah yang ditanda tangani akadnya bisa berjalan sesuai prosedur. ${ }^{38}$

\footnotetext{
${ }^{37}$ Ah. Azharuddin Lathif, "Konsep dan Aplikasi Akad Murabahah pada Perbankan Syariah di Indonesia", Jurnal Ahkam, Vol. XII, No. 2, Juni 2012, hlm. 72

${ }^{38}$ Yenti Afrida, "Analisis Pembiayaan Murabahah di Perbankan Syariah", JEBI (Jurnal Ekonomi dan Bisnis Islam), Vol. 1, No. 2, Juli-Desember 2016, hlm. 162
} 


\section{SKEMA MURABAHAH}

\section{Aplikasi Teknis Pembiayaan Perbankan dengan Akad Wakalah}

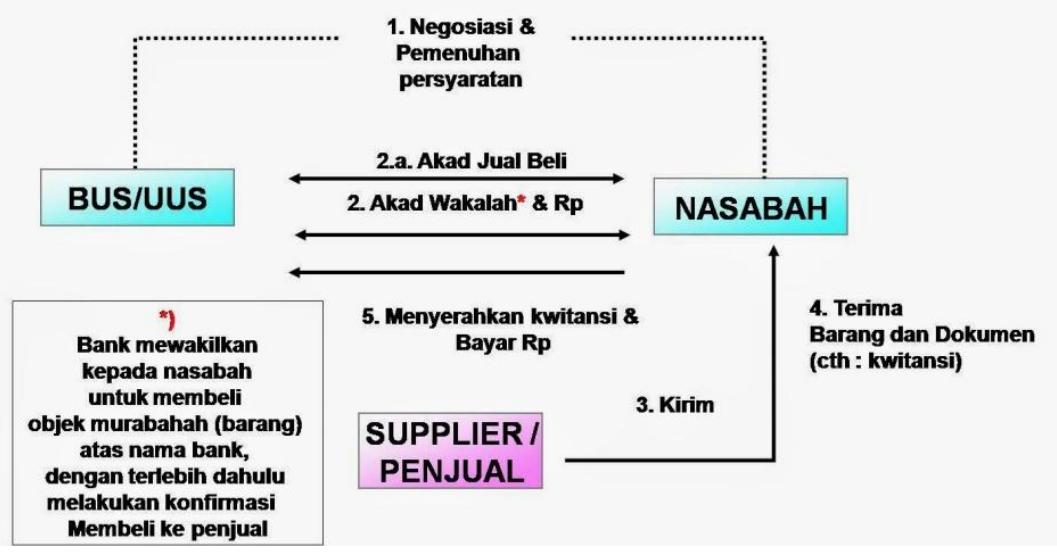

Keterangan:

1. Bank syariah dan nasabah melakukan negosiasi tentang rencana transaksi jual beli yang akan dilaksanakan.

2. a. Bank syariah melakukan akad jual beli dengan nasabah dimana bank syariah sebagai penjual dan nasabah sebagai pembeli.

b. Bank syariah mewakilkan kepada nasabah untuk membeli objek murabahah (barang) atas nama bank, dengan terlebih dahulu melakukan konfirmasi membeli ke penjual.

3. Supplier mengirimkan barang kepada nasabah atas perintah bank syariah.

4. Nasabah menerima barang dari supplier dan menerima dokumen kepemilikan barang tersebut.

5. Nasabah menyerahkan bukti pembelian barang kepada bank dan melakukan pembayaran baik secara tunai maupun angsuran.

Praktik murabahah bil wakalah hukumnya mubah jika dilakukan sesuai dengan konsep fiqih dimana bank bertindak sebagai penjual barang yang harganya sudah jelas seperti pembelian mobil di dealer, kemudian untuk memudahkan nasabah dalam memilih karakteristik dari barang yang akan dibeli, maka bank mewakilkan pembelian kepada nasabah. Maka dalam prakteknya bank dan nasabah tidak boleh melakukan akad murabahah terlebih dahulu tetapi hendaknya melakukan 
akad wakalah terlebih dahulu agar barang yang dibeli menjadi milik bank dan tidak langsung berpindah kepemilikan pada nasabah. ${ }^{39}$

Aplikasi murabahah bil wakalah yang sah adalah bank mewakilkan pembelian barang kepada nasabah atas izin dan kuasa dari bank, dan akad dibuat secara terpisah. Fatwa Dewan Syariah Nasional No. 04/DSNMUI/IV/2000 tentang murabahah pada poin 9 disebutkan "jika bank hendak mewakilkan kepada nasabah untuk membeli barang dari pihak ketiga, akad jual beli murabahah harus dilakukan setelah barang, secara prinsip, menjadi milik bank" 40

Namun aplikasi murabahah bil wakalah seringkali menimbulkan kecurangan side streaming yang berarti penggunaan dana yang tidak sesuai dengan akad perjanjian awal. Adanya akad wakalah akan membebaskan nasabah untuj membeli barang sendiri tanpa ada pendampingan dari pihak bank syari'ah yang berakibat pada tidak sah-nya akad murabahah. Kecurangan ini dilakukan nasabah dengan memalsukan kwitansi atau bukti pembelian sehingga kecurangan tersebut tidak diketahui oleh bank syariah. ${ }^{41}$

4. Analisis perbandingan murabahah di perbankan syariah dengan jual-beli di merchant.

\begin{tabular}{|c|c|}
\hline Murabahah di Perbankan & Jual beli di Merchant \\
\hline Ada biaya administrasi & Tidak ada biaya administrasi \\
\hline $\begin{array}{l}\text { Proses transaksi lama } \\
\text { dikarenakan bank harus membeli } \\
\text { barang atau aset yang diinginkan }\end{array}$ & $\begin{array}{l}\text { Proses transaksi cepat karena } \\
\text { merchant memiliki barang atau } \\
\text { aset yang diinginkan oleh }\end{array}$ \\
\hline
\end{tabular}

\footnotetext{
${ }^{39}$ Yenti Afrida, "Analisis Pembiayaan Murabahah di Perbankan Syariah", JEBI (Jurnal Ekonomi dan Bisnis Islam), Vol. 1, No. 2, Juli-Desember 2016, hlm. 164

${ }^{40}$ Fatwa Dewan Syariah Nasional No. 04/DSN-MUI/IV/2000 tentang Murabahah dikutip dari https://dsnmui.or.id/produk/fatwa/ diakses pada 12 Maret 2018, pukul 23:20 WIB.

${ }^{41}$ Mufti Afif dan Richa Angkita Mulyawisdawati, "Celah Riba pada Perbankan Syariah serta Konsekwensinya Terhadap Individu, Masyarakat dan Ekonomi”, Jurnal Cakrawala, Vol. XI, No. 1, 2016, hlm. 11
} 


\begin{tabular}{|l|l|}
\hline Oleh nasabah terlebih dahulu & nasabah \\
\hline $\begin{array}{l}\text { Pembayaran bisa dengan tunai } \\
\text { dan cicil }\end{array}$ & $\begin{array}{l}\text { Tidak semua merchant mau } \\
\text { menerima pembayaran secara } \\
\text { cicil }\end{array}$ \\
\hline $\begin{array}{l}\text { Melibatkan } 3 \text { pihak bank, } \\
\text { nasabah dan pihak ke } 3 \\
\text { (supplier) }\end{array}$ & Hanya 2 pihak, penjual dan \\
pembeli
\end{tabular}

\section{PENUTUP}

Dalam praktik di LKS kontemporer, termasuk di dalamnya perbankan syariah, bentuk murabahah dalam fiqih klasik mengalami beberapa modifikasi. Modifikasi dalam murabahah meliputi modifikasi definisi murabahah yang semula menempatkan bank syariah sebagai penjual namun kini bank syariah hanya menjadi penyedia dana.

Akad murabahah juga mengalami modifikasi yang memberi kemudahan pada LKS selaku pelaksana akad ini. Modifikasi dalam akad murabahah seperti mengikat nasabah dengan janji untuk membeli barang yang akan ditawarkan oleh LKS, sedangkan LKS belum memiliki barang yang dipesan oleh nasabah. Modifikasi lainnya yaitu pada akad murabahah lil amri bi al-syira' yang dibolehkan oleh sebagian ulama karena kembali pada hukum asal dari muamalah yaitu boleh, namun sebagian ulama yang lain mengatakan akad ini haram karena merupakan hilah untuk menghalalkan riba. Modifikasi lainnya ada pada murabahah bil wakalah yang diperbolehkan oleh fatwa DSN-MUI No. 04/DSNMUI/IV/2000 poin 9, namun adanya akad wakalah menyebabkan munculnya kecurangan atau side streaming.

\section{DAFTAR PUSTAKA}

Afif, Mufti dan Richa Angkita Mulyawisdawati. 2016. Celah Riba pada Perbankan Syariah serta Konsekwensinya Terhadap Individu, Masyarakat dan Ekonomi. Jurnal Cakrawala. Vol. XI, No. 1. 
Afrida, Yenti. 2016. Analisis Pembiayaan Murabahah di Perbankan Syariah. JEBI (Jurnal Ekonomi dan Bisnis Islam). Vol. 1.No. 2.

Al-'Asqalani, Ibnu Hajar. 2006. Subulu as-Salam Syarhu Bulughul Maram.

Cet-I. Riyadh. Maktabah al-Ma'arif.

Antonio, Muhammad Syafi'i. 2001. Bank Syariah dari Teori ke Praktik. Cet-

I. Jakarta. Gema Insani Press.

Budiono, Arief. 2017. Penerapan Prinsip Syariah pada Lembaga Keuangan Syariah. Jural Law and Justice. Vol. 2, No. 1.

Fatwa Dewan Syariah Nasional No. 04/DSN-MUI/IV/2000 tentang Murabahah. dikutip dari https://dsnmui.or.id/produk/fatwa/ diakses pada 12 Maret 2018. pukul 23:20 WIB.

Fatwa DSN-MUI No. 04/DSN-MUI/IV/2000 tentang Murabahah, https://dsnmui.or.id/produk/fatwa/ diakses pada 21 April 2018, pukul 22:02 WIB

Ibnu Katsir ad-Damasyqi, al-Imam Abul Fida Ismail. 2000. Tafsir Ibnu Katsir. terj. Bahrun Abu Bakar. Cet-I. Bandung. Sinar Baru Algensindo.

Ibnu Mandzur, Imam al-'Alamah. 1999. Lisanul Arab. Juz 5. Cet-3. Beirut.

Dar Ehia al-Toutath al-Arabi.

Ismail. 2011. Perbankan Syariah. Jakarta. Kencana.Lathif.

Ah. Azharuddin. 2012. Konsep dan Aplikasi Akad Murabahah pada Perbankan Syariah di Indonesia. Jurnal Ahkam. Vol. XII. No. 2.

Yusuf, Muhammad. 2013. Analisis Penerapan Pembiayaan Murabahah Berdasarkan Pesanan dan Tanpa Pesanan serta Kesesuaian dengan PSAK 102. BINUS BUSINESS REVIEW. Vol.4, No.1.

Lidinillah, Achmad Hijri. Imron Mawardi. 2015. Praktik Gharar pada Hubungan Bisnis UMKM-Eksportir Furnitur di Jepara. Jurnal JESTT. Universitas Airlangga. Vol. 2, No. 2

Martono. 2007. Bank dan Lembaga Keuangan Lain. Cet-4. Yogyakarta. Ekonisia.

Naimah. Down Payment (DP) dalam Pembiayaan Murabahah. Prespektif Fikih Mu'amalah. https://media.neliti.com/media/publications/30006- 
ID-down-payment-dp-dalam-pembiayaan-murabahah-perspektiffikih-muamalah.pdf, diakses pada 21 April 2018, pukul: 22:56 WIB

Nur Baits, Ammi Skema. Murabahah Syariah. dikutip dari https://pengusahamuslim.com/4942-skema-murabahah-

syariah.html. diakses pada 12 Maret 2018. Pukul 02:31 WIB.Soemitra, Andri. 2009. Bank dan Lembaga Keuangan Syari'ah.

Cet ke 3. Jakarta. Kencana Prenada Media Grup.

PSAK 102 Akuntansi Murabahah. http://iaiglobal.or.id/v03/standarakuntansi-keuangan/pernyataan-sas-65-psak-102-akuntansimurabahah. diakses pada 21 April 2018. pukul 22:04 WIB.

Purnamasari, Irma devita. Panduan Lengkap Hukum Praktis Populer KiatKiat Cerdas, Mudah, dan Bijak Memahami Masalah Akad Syariah. Surat Edaran Otoritas jasa Keuangan (SEOJK) No. 36/SEOJK.03/2015. https://www.ojk.go.id/id/kanal/perbankan/regulasi/surat-edaran-ojk/Pages/-

SEOJK-Nomor-36032015-tentang-Produk-dan-Aktivitas-bus-

uus.aspx. diakses pada 21 April 2018. pukul 22: 06 WIB.

UU No. 21 Tahun 2008 Tentang Perbankan Syariah.

https://www.bi.go.id/id/perbankan/syariah/Documents/UU_21_08_Syariah. diakses pada 21 April 2018. pukul 22:09 WIB.

Za'tari, 'Alauddin. 2002. Al-Khidmah Al-Mashrafiyyah. Cetakan I, Damaskus. Dar el-Kalam Attayyib.

Zuhaili, Wahbah. 1985. al-Figh al-Islami wa Adillatuhu. Juz 4. Cet-2. Damaskus. Dar al-Fikr. 